\title{
Anti-Inflammatory, Antioxidant, and Wound-Healing Properties of Cyanobacteria from Thermal Mud of Balaruc-Les-Bains, France: A Multi-Approach Study
}

\author{
Justine Demay ${ }^{1,2}{ }^{(}$, Sébastien Halary ${ }^{1}$, Adeline Knittel-Obrecht ${ }^{3,4}$, Pascal Villa ${ }^{3,4}{ }^{\circledR}$, Charlotte Duval ${ }^{1}$, \\ Sahima Hamlaoui ${ }^{1}$, Théotime Roussel ${ }^{1}$, Claude Yéprémian ${ }^{1}$, Anita Reinhardt ${ }^{2}$, Cécile Bernard ${ }^{1, *}$ \\ and Benjamin Marie ${ }^{1, *} \mathbb{C}$
}

\section{check for}

updates

Citation: Demay, J.; Halary, S.; Knittel-Obrecht, A.; Villa, P.; Duval,

C.; Hamlaoui, S.; Roussel, T.;

Yéprémian, C.; Reinhardt, A.;

Bernard, C.; et al. Anti-Inflammatory,

Antioxidant, and Wound-Healing

Properties of Cyanobacteria from

Thermal Mud of Balaruc-Les-Bains,

France: A Multi-Approach Study.

Biomolecules 2021, 11, 28. https://

doi.org/10.3390/biom11010028

Received: 22 November 2020

Accepted: 22 December 2020

Published: 29 December 2020

Publisher's Note: MDPI stays neutral with regard to jurisdictional claims in published maps and institutional affiliations.

Copyright: (C) 2020 by the authors. Licensee MDPI, Basel, Switzerland. This article is an open access article distributed under the terms and conditions of the Creative Commons Attribution (CC BY) license (https: / / creativecommons.org / licenses/by/4.0/).
1 UMR7245 MCAM MNHN-CNRS, Muséum National d'Histoire Naturelle, CP 39, 12 Rue Buffon, F-75231 Paris, CEDEX 05, France; justine.demay1@mnhn.fr (J.D.); sebastien.halary@mnhn.fr (S.H.); charlotte.duval@mnhn.fr (C.D.); sahima.hamlaoui@mnhn.fr (S.H.); theotime.roussel@mnhn.fr (T.R.); claude.yepremian@mnhn.fr (C.Y.)

2 Thermes de Balaruc-Les-Bains, 1 Rue du Mont Saint-Clair BP 45, 34540 Balaruc-Les-Bains, France; anita.reinhardt@thermesbalaruc.com

3 CNRS, Université de Strasbourg, PCBIS Plate-Forme de Chimie Biologique Intégrative de Strasbourg UMS, 3286, F-67412 Illkirch, France; aobrecht@unistra.fr (A.K.-O.); pvilla@unistra.fr (P.V.)

4 Labex MEDALIS, F-67000 Strasbourg, France

* Correspondence: cecile.bernard@mnhn.fr (C.B.); benjamin.marie@mnhn.fr (B.M.); Tel.: +33-1-40-79-31-83 (C.B.); +33-1-40-79-32-12 (B.M.)

\begin{abstract}
Background: The Balaruc-les-Bains' thermal mud was found to be colonized predominantly by microorganisms, with cyanobacteria constituting the primary organism in the microbial biofilm observed on the mud surface. The success of cyanobacteria in colonizing this specific ecological niche can be explained in part by their taxa-specific adaptation capacities, and also the diversity of bioactive natural products that they synthesize. This array of components has physiological and ecological properties that may be exploited for various applications. Methods: Nine cyanobacterial strains were isolated from Balaruc thermal mud and maintained in the Paris Museum Collection (PMC). Full genome sequencing was performed coupled with targeted and untargeted metabolomic analyses (HPLC-DAD and LC-MS/MS). Bioassays were performed to determine antioxidant, antiinflammatory, and wound-healing properties. Results: Biosynthetic pathways for phycobiliproteins, scytonemin, and carotenoid pigments and 124 metabolite biosynthetic gene clusters (BGCs) were characterized. Several compounds with known antioxidant or anti-inflammatory properties, such as carotenoids, phycobilins, mycosporine-like amino acids, and aeruginosins, and other bioactive metabolites like microginins, microviridins, and anabaenolysins were identified. Secretion of the proinflammatory cytokines TNF- $\alpha$, IL-1 $\beta$, IL-6, and IL-8 appeared to be inhibited by crude extracts of Planktothricoides raciborskii PMC 877.14, Nostoc sp. PMC 881.14, and Pseudo-chroococcus couteii PMC 885.14. The extract of the Aliinostoc sp. PMC 882.14 strain was able to slightly enhance migration of HaCat cells that may be helpful in wound healing. Several antioxidant compounds were detected, but no significant effects on nitric oxide secretion were observed. There was no cytotoxicity on the three cell types tested, indicating that cyanobacterial extracts may have anti-inflammatory therapeutic potential without harming body cells. These data open up promising uses for these extracts and their respective molecules in drugs or thermal therapies.
\end{abstract}

Keywords: cyanobacteria; thermal mud; natural products; anti-inflammatory; bioactivity

\section{Introduction}

Cyanobacteria, the so-called blue-green algae, are an ancient lineage of photosynthetic prokaryotes found worldwide. They are notorious for their harmful effects on human health because they produce toxins such as microcystins, anatoxins, and saxitoxins [1-3]. 
Not all species synthesize cyanotoxins, and cyanobacterial compounds such as pigments and specialized metabolites have been studied for their beneficial actions against cancer and as antioxidants and anti-inflammatories [4,5]. In recent years, the improvement of genome sequencing techniques and the increasing number of available genomes uncovered the great potential for specialized metabolite production by cyanobacteria [6-9]. Specialized metabolites, also known as secondary metabolites or natural products, are widespread in plants, fungi, and bacteria, but are especially abundant in cyanobacteria [10]. In cyanobacteria, genome exploration has revealed numerous biosynthetic gene clusters belonging to non-ribosomal pathways. These include non-ribosomal peptide synthetase (NRPS), polyketide synthetase (PKS), and members of other ribosomal pathways, such as ribosomally synthesized and post-translationally modified peptide (RiPPs), terpene, or alkaloid pathways $[8,11]$. Thanks to the diverse metabolic activity of cyanobacteria, their natural products have attracted a great deal of interest in research for new bioactive substances [12-15].

Benthic cyanobacteria especially have shown a wide range of specialized metabolites. This is illustrated by the remarkable number of compounds isolated from the Lyngbya majuscula-Moorea producens genus [4,9]. Because they are attached to a substrate, benthic cyanobacteria are subject to intense space competition and to stresses like desiccation, high light intensity, and predation by grazers that forced them to develop a large repertoire of chemical defences [16-18]. Therapeutic thermal mud from the thermal baths of Balaruc-les-Bains (France) has been used to treat various illnesses since ancient Roman times. For joint diseases such as osteoarthritis and rheumatism, the matured thermal mud (peloid) is applied directly to the patient's skin. Two studies were conducted in the $1980 \mathrm{~s}$ to evaluate the specific algal communities colonizing this peloid, and both showed that diverse genera of microalgae and cyanobacteria have colonized the mud with a predominance of cyanobacteria belonging to the Phormidium genus $[19,20]$. It was hypothesized that compounds produced by this microflora, in association with heat and microelements in the hot spring water, were responsible for the beneficial therapeutic properties of Balarucles-Bains mud, as proposed for other thermal baths [21-23]. However, the thermal mud of Balaruc-Les-Bains still remains a relatively unexplored environment, particularly with regard to identifying the therapeutically active compounds produced by the microflora associated with the mud.

In 2014, a new isolation campaign was initiated to ascertain the evolution of the microbial communities in the maturing mud during the five-month summer period. Several species of cyanobacteria and microalgae were isolated and maintained in the Paris' Museum Collection (PMC) [24]. Nine cyanobacteria, belonging to four different orders with different morphotypes (Table 1), were selected for assessment of metabolite production, as they belong to genera considered as prolific producers of potent bioactive compounds.

Table 1. List of cyanobacterial strains isolated from the Balaruc thermal mud and their corresponding strain reference numbers. PMC: Paris' Museum Collection.

\begin{tabular}{llcc}
\hline \multicolumn{1}{c}{ Order } & \multicolumn{1}{c}{ Species } & Strain Number & BioProject Accession Numbers \\
\hline Chroococcales & Pseudo-chroococcus couteii & PMC 885.14 & PRJNA686263 \\
Synechococcales & Leptolyngbya boryana & PMC 883.14 & PRJNA686260 \\
& Planktothricoides raciborskii & PMC 877.14 & PRJNA686238 \\
& Laspinema sp. & PMC 878.14 & PRJNA686242 \\
Oscillatoriales & Microcoleus vaginatus & PMC 879.14 & PRJNA686244 \\
& Lyngbya martensiana & PMC 880.14 & PRJNA686257 \\
& Nostoc sp. & PMC 881.14 & PRJNA686259 \\
Nostocales & Aliinostoc sp. & PMC 882.14 & PRJNA686262 \\
& Calothrix sp. & PMC 884.14
\end{tabular}

To take advantage of the diverse bioactivities of the compounds produced by cyanobacteria, the anti-inflammatory, antioxidant, and wound-healing potential of the nine strains 
(Table 1) were investigated. Numerous compounds produced by these cyanobacteria have been described, including pigments, such as phycobilins, chlorophylls, carotenoids, and scytonemin, and specialized metabolites-mycosporine-like amino acids, aeruginosins, and honaucins $[4,25]$. The simple screening for activity as a way to identify new therapeutic metabolites has recently been greatly accelerated by improved genome sequencing methods and the development of genome mining to identify and characterize specialized metabolite biosynthetic gene clusters (BGCs) [26]. In consequence, the metagenomes of the present nine Balaruc cyanobacterial strains have been sequenced in-depth and biosynthetic genes for pigments and specialized metabolites have been characterized. Targeted pigment dose studies have been performed and untargeted LC-MS/MS investigations have been developed to determine the diversity of compounds produced by the nine strains. In parallel, crude water and methanol extracts have been tested for anti-inflammatory, antioxidant, wound-healing, and cytotoxic properties to evaluate their potential for further therapeutic development.

\section{Materials and Methods}

\subsection{Biological Material}

Nine monoclonal cyanobacteria strains were isolated in 2014 from thermal mud in Balaruc-Les-Bains, France, and have been maintained as non-axenic cultures in the Paris Museum Collection (PMC) (Table 1) [24]. Sampling and taxonomy of the strains were described elsewhere [27]. The isolated cyanobacteria were grown in Z8 medium at $24{ }^{\circ} \mathrm{C}$. During experiments, the cultures were maintained in 1-L Duran bottles with a photon flux density of $12 \mu \mathrm{mol} \cdot \mathrm{m}^{-2} \cdot \mathrm{s}^{-1}$ (PAR, photosynthetical active radiation) and a 16:8 h light:dark cycle. Cultures were transferred into fresh $\mathrm{Z} 8$ medium every six weeks to maintain them in the active growth phase.

\subsection{Genome Sequencing and Assembly}

After a centrifugation step of $150 \mathrm{~mL}$ cultures of each strain, DNA extractions were performed on the pellets using the ZymoBIOMICS DNA mini kit (Zymo Research, Irvine, CA, USA) following the manufacturer's protocol. The Macherey Nagel genomic DNA and total RNA purification kit with NucleoBond AXG20 columns and buffer set III (MachereyNagel, PA, USA) was employed for PMC 881.14 and PMC 884.14. Metagenome sequencing was performed by GenoScreen (GenoScreen, Lille, France) using the Nextera XT DNA sample preparation kit (Illumina) for $2 \times 250$ bp and using a SMRT2 cell (PacBio) Illumina and Pacbio raw reads were corrected using SPAdes 3.12 and Canu 1.8, respectively, before the assembly performed with Unicycler hybrid-assembler, with default parameters [28-30]. For each new assembly, scaffolds were binned using MyCC (k-mer size $=4$, minimal sequence size $=1000$ ) and taxonomically annotated using CAT [31]. Congruent data between both methodologies allowed to characterize the cyanobacteria draft genomes.

\subsection{In Silico Analyses}

The genome assemblies were integrated on the MicroScope platform v3.14.1 (https: / / mage.genoscope.cns.fr/microscope/home/index.php) [32]. Biosynthetic gene clusters (BGCs) for specific metabolites were identified using the antiSMASH v5.0.0 [33] and MIBiG v1.4 [34] software available through the MicroScope platform. These tools allowed characterization of the gene cluster organization and predicted the molecules potentially produced by comparison of homologies between the query and the BGC sequences annotated in the databases. For each BGC identified, we carefully checked the automatic prediction against the literature on the biosynthetic pathways described to obtain a "curated" annotation of the detected clusters with the highest confidence possible. As the automatic annotation tools did not detect pigment biosynthetic genes, a targeted approach was performed using BLASTp and the search-by-keywords function of the MicroScope platform. 


\subsection{Pigment Composition Analysis}

The pigment composition of the strains was determined in triplicate from $10 \mathrm{~mL}$ of culture filtered through Whatman GF/F filters $(\varnothing 0.7 \mu \mathrm{m})$ and freeze dried. For extracting lipid-soluble pigments like carotenoids and chlorophylls, filtered biomasses were extracted with methanol, pooled, and quantified by HPLC-DAD (as described in Ras et al., 2008) [35]. For determination of the water-soluble phycobiliprotein pigments, filtered biomasses were analyzed following a published procedure [36].

\subsection{Metabolite Extraction, Analysis by Mass Spectrometry, and Annotation}

For each cyanobacterial strain, biomasses from five successive subcultures $(5 \times 500 \mathrm{~mL})$ were collected at the end of the exponential growth and centrifuged at $3220 \times g$ for $10 \mathrm{~min}$. The pellets were lyophilized (Freezone $2.5 \mathrm{~L}$, Labconco, Italia) and pooled for metabolite extraction. Two different metabolite extractions were performed with the same pooled samples (200 mg dried weight) to increase the likelihood of identifying all the metabolites: (1) a mild hydrophobic single extraction with $\mathrm{MeOH} /$ water, $75 \% / 25 \%, v / v$ (solvent $\mathrm{A}$ ) and (2) a hydrophilic single extraction with ultrapure water acidified with $0.1 \%$ formic acid (solvent B). Lyophilized cell pellets were weighed and $1 \mathrm{mg}$ in $100 \mu \mathrm{L}$ of the extraction solution was sonicated (SONICS Vibra Cell, 130 Watt, $20 \mathrm{Khz}$ ) at $80 \%$ power three times for two minutes each time ( $30 \mathrm{~s}$ rest between). Prior to analysis, the sonicated extracts were centrifuged at $12,000 \times \mathrm{g}$ for $10 \mathrm{~min}$ at $4{ }^{\circ} \mathrm{C}$. Four microliters aliquots of the supernatants were run on an ultra-high-performance liquid chromatograph (UHPLC Ultimate 3000, Thermo, Waltham, MA, USA) using a Polar Advances II 2.5 pore C18 column (Thermo, Waltham, MA, USA) at a $300 \mu \mathrm{L} \cdot \mathrm{min}^{-1}$ flow rate with a linear gradient of acetonitrile in $0.1 \%$ formic acid (5-90\% for $21 \mathrm{~min}$ ) coupled with a high-resolution mass spectrometer. Chromatography runs were done in triplicate. The eluted metabolites were analyzed using an electrospray ionization hybrid quadrupole time-of-flight (ESI-QqTOF) high-resolution mass spectrometer (Compact Bruker, Bremen, Germany) in positive simple MS or positive autoMS/MS mode with information-dependent acquisition (IDA), on the 50 to $1500 \mathrm{~m} / \mathrm{z}$ range at $2 \mathrm{~Hz}$ or between 2 and $8 \mathrm{~Hz}$ speed, for MS and MS/MS, respectively, according to relative intensity of parent ions, in consecutive cycle times of $2.5 \mathrm{~s}$, with an active exclusion of previously analysed parents. The data were analyzed with the DataAnalysis 4.4 software for internal recalibration $(<0.5 \mathrm{ppm})$ and MGF exports were generated from MS/MS spectra between 1 and $15 \mathrm{~min}$. The raw MS and MS/MS data were analyzed with MetaboScape 4.0 software (Bruker, Bremen, Germany) to automatically search and group together all classical adduct forms $\left([\mathrm{M}+\mathrm{H}]^{+},[\mathrm{M}+2 \mathrm{H}]^{+},[\mathrm{M}+3 \mathrm{H}]^{+},[\mathrm{M}+\mathrm{Na}]^{+},[\mathrm{M}+\mathrm{K}]^{+}\right.$, and $\left.\left[\mathrm{M}+\mathrm{NH}_{4}\right]^{+}\right)$ using a threshold value of 0.8 for the co-elution coefficient factor. Metabolite annotation was attempted according to the precise mass of the molecules and their respective MS/MS fragmentation patterns with regards to MS/MS libraries (NIH, GNPS, EMBL, MassBank, ReSpect, etc.) and the CyanoMet database [37] of $>2100$ cyanobacterial metabolites. Results were confirmed by running 36 commercially available standards of specific cyanobacterial metabolite families: cyanopeptolins, aeruginosins, microginins, anabaenopeptins, aerucyclamides, microcystins, saxitoxins, anatoxins, and cylindrospermopsins.

\subsection{Molecular Networking}

MetGem v1.2.2 [38] was used to create a molecular network from the MS/MS data (in $\mathrm{mgf}$ format) for two out of the nine extracts. The network was created with edges filtered to have a cosine score above 0.65 and more than four matched peaks. Further edges between two nodes were retained in the network only if each of the nodes appeared in each of the other's top ten most similar nodes, respectively. The MetGem database search function was used to screen each spectrum against GNPS and ISDB spectral libraries.

\subsection{Bioassays}

Activity assays were performed using crude extracts from the same nine cyanobacteria as for metabolomic analysis and the same method with solvents A and B. Methanol 
extracts were evaporated with a RotaVap R-210 (Büchi, Flawil, Switzerland) and aqueous extracts were lyophilized. Each was then resuspended in DMSO/water $(50 \% / 50 \%)$ at a concentration of $30 \mathrm{mg} \cdot \mathrm{mL}^{-1}$ (dried extract).

The antioxidant potential of the crude extracts was assessed by measuring nitric oxide (NO) production by the macrophage-like cell line, RAW 264.7, stimulated with $5 \mu \mathrm{g} \cdot \mathrm{mL}^{-1}$ lipopolysaccharide (LPS, Sigma L6636). Quercetol was used as the positive antioxidant control and results were expressed as percent inhibition compared to the maximal $\mathrm{NO}$ level induced by LPS in $0.1 \%$ DMSO [39]. Following $24 \mathrm{~h}$ of treatment, NO production was determined indirectly with quantification of nitrite $\left(\mathrm{NO}_{2}{ }^{-}\right)$accumulation in culture media using Griess Reaction. Briefly, $100 \mu \mathrm{L}$ of Griess reagent (Invitrogen G-7921) was added to $100 \mu \mathrm{L}$ of cellular supernatant samples into 96-well plates (Greiner 655101) and left $30 \mathrm{~min}$ at room temperature under shaking. Absorbance at $540 \mathrm{~nm}$ was measured using an Envision (Perkin Elmer) microplate reader. The reduction or increase in nitrite levels was calculated by the percentage of absorbance of sample relative to the positive control (5 $\mu \mathrm{g} \cdot \mathrm{mL}^{-1}$ LPS with $0.1 \%$ DMSO).

Anti-inflammatory activity of the extracts was evaluated by determining their effect on the concentration of the proinflammatory cytokines, TNF $\alpha$, IL-1 $\beta$, IL-6, and IL-8, in human peripheral blood mononuclear cells (PBMCs). PBMCs were stimulated with $5 \mu \mathrm{g} \cdot \mathrm{mL}^{-1}$ LPS and the extracts were then added. Cytokine concentration was then measured using HTRF technology with fluorescent antibodies [39]. Dexamethasone was used as positive control and results were expressed as percent inhibition relative to the maximal cytokine secretion induced by LPS.

Cell migration assays were performed using the HaCat cell line of human keratinocytes. Extracts were pipetted onto HaCat monolayers previously wounded and treated to prevent cell proliferation. The plate was then placed into the IncuCyte ${ }^{\mathrm{TM}}$ (Essen Bioscience, Ann Arbor, MI) live-cell imaging instrument to measure the cell migration onto the wounded area for $48 \mathrm{~h}$. Fetal bovine serum (FBS) was used as positive control as it enhances cell migration onto the wounded area [40].

Cell viability was also measured during the three previous tests with the WST-1 assay (Ozyme, Saint-Quentin-en-Yvelines, France) following protocol described previously [41] in order to validate the bioassay results and to assess the potential cytotoxicity of the crude extracts. For this test, an extract was considered cytotoxic if the cell viability was less than $70 \%$ [39].

\section{Results}

\subsection{Characteristics of the Cyanobacterial Genomes}

Results of analysis of the nine cyanobacterial genomes are presented in Table 2. High CheckM completeness scores $(>97.1 \%)$ indicate that the genomes were mostly complete and well assembled. A low contamination score $(<1.4 \%)$ was found for all genomes, which means a low risk of potential contamination of assemblies with exogenous sequences. The mean size of the genomes was $7.8 \mathrm{Mb}$, ranging from $5.8 \mathrm{Mb}$ for the Pseudo-chroococcus strain, PMC 885.14, to $13.2 \mathrm{Mb}$ for the Calothrix sp., PMC 884.14. An important difference was observed between the numbers of contigs for each strain, which ranged from five contigs for L. boryana, PMC 883.14, to 648 for Nostoc sp., PMC 881.14.

\subsection{Pigment Composition}

Pigments are some of the primary metabolites that exhibit potent antioxidant and/or anti-inflammatory properties. Thus, we investigated the biosynthetic pathways of the phycobiliproteins, scytonemin, carotenoids, and chlorophylls in the nine strain genomes (Table 3). 


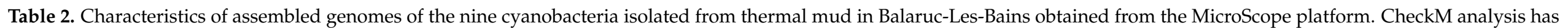
been performed for each genome using reference genomes (65-89 for 520-584 lineage-specific markers). CDS: Coding sequences.

\begin{tabular}{|c|c|c|c|c|c|c|c|c|c|}
\hline Genus/Species & Strain & Genome Length (bp) & GC Content & Number of Contigs & Number of CDS & Number of rRNA & Average CDS Length (bp) & CheckM Completeness & CheckM Contamination \\
\hline P. raciborskii & PMC 877.14 & $7,392,957$ & $44 \%$ & 15 & 7130 & 12 & 841.8 & $99.9 \%$ & $0.89 \%$ \\
\hline Laspinema sp. & PMC 878.14 & $7,343,542$ & $47 \%$ & 69 & 5829 & 9 & 1022.4 & $99.3 \%$ & $1.16 \%$ \\
\hline M. vaginatus & PMC 879.14 & $6,904,242$ & $46 \%$ & 34 & 6400 & 6 & 904.5 & $99.6 \%$ & $0.22 \%$ \\
\hline L. martensiana & PMC 880.14 & $6,457,204$ & $40 \%$ & 132 & 5904 & 3 & 937.8 & $97.1 \%$ & $1.19 \%$ \\
\hline Nostoc sp. & PMC 881.14 & $8,003,053$ & $42 \%$ & 648 & 7711 & 3 & 845.9 & $99.5 \%$ & $1.19 \%$ \\
\hline Aliinostoc sp. & PMC 882.14 & $8,136,653$ & $41 \%$ & 46 & 7582 & 12 & 883.9 & $98.2 \%$ & $0.22 \%$ \\
\hline L. boryana & PMC 883.14 & $6,695,177$ & $47 \%$ & 5 & 6313 & 9 & 929.1 & $99.4 \%$ & $1.02 \%$ \\
\hline Calothrix sp. & PMC 884.14 & $13,247,652$ & $39 \%$ & 46 & 11,176 & 15 & 891.3 & $99.3 \%$ & $1.35 \%$ \\
\hline P. couteii & PMC 885.14 & $5,871,606$ & $35 \%$ & 137 & 5328 & 6 & 946.5 & $98.5 \%$ & $1.31 \%$ \\
\hline
\end{tabular}

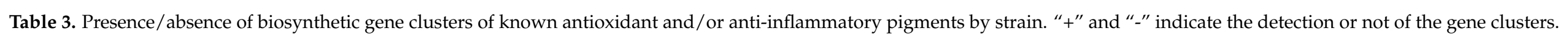

\begin{tabular}{|c|c|c|c|c|c|c|c|c|c|c|}
\hline \multicolumn{2}{|c|}{ Pigments } & \multirow{2}{*}{$\begin{array}{c}\text { P. raciborskii } \\
\text { PMC 877.14 } \\
+\end{array}$} & \multirow{2}{*}{$\begin{array}{c}\text { Laspinema sp. } \\
\text { PMC 878.14 } \\
+\end{array}$} & \multirow{2}{*}{$\begin{array}{c}\text { M. vaginatus } \\
\text { PMC 879.14 } \\
+\end{array}$} & \multirow{2}{*}{$\begin{array}{l}\text { L. martensiana } \\
\text { PMC 880.14 } \\
++\end{array}$} & \multirow{2}{*}{$\begin{array}{c}\text { Nostoc sp. } \\
\text { PMC 881.14 } \\
+\end{array}$} & \multirow{2}{*}{$\begin{array}{c}\text { Aliinostoc sp. } \\
\text { PMC 882.14 } \\
+\end{array}$} & \multirow{2}{*}{$\begin{array}{c}\begin{array}{c}\text { L. boryana } \\
\text { PMC 883.14 }\end{array} \\
+\end{array}$} & \multirow{2}{*}{$\begin{array}{c}\begin{array}{c}\text { Calothrix sp. } \\
\text { PMC 884.14 }\end{array} \\
+\end{array}$} & \multirow{2}{*}{$\begin{array}{c}\begin{array}{c}\text { P. couteii } \\
\text { PMC 885.14 }\end{array} \\
+\end{array}$} \\
\hline Phycobiliproteins & C-Phycocyanin & & & & & & & & & \\
\hline & Allophycocyanin & + & + & + & + & + & + & + & + & + \\
\hline & Phycoerythrin & + & - & - & - & + & - & - & + & + \\
\hline Scytonemin & & - & - & - & - & + & + & - & + & - \\
\hline \multirow[t]{4}{*}{ Hydroxylated carotenoids } & Cryptoxanthin & + & + & + & + & + & + & + & + & + \\
\hline & Zeaxanthin & + & + & + & + & + & + & + & + & + \\
\hline & Caloxanthin & - & + & - & + & - & + & + & + & - \\
\hline & Nostoxanthin & - & + & - & + & - & + & + & + & - \\
\hline \multirow[t]{4}{*}{ Myxoxanthophylls } & 1-hydroxylycopene & + & + & + & + & + & + & + & + & + \\
\hline & $1^{\prime}$-Hydroxy- $\gamma$-carotene & + & + & + & + & + & + & + & + & + \\
\hline & Myxol 2'-pentoside & + & + & + & + & + & + & + & + & + \\
\hline & $\begin{array}{l}\text { 2-Hydroxymyxol } \\
\text { 2'-methylpentoside }\end{array}$ & - & + & - & + & - & + & + & + & - \\
\hline Echinenone & & - & + & + & + & + & + & + & + & + \\
\hline \multirow{2}{*}{ Ketocarotenoids } & Canthaxanthin & - & + & + & + & + & + & + & + & + \\
\hline & Adonixanthin & - & + & + & + & + & + & + & + & + \\
\hline
\end{tabular}


Phycocyanin pathways were identified in all nine cyanobacteria, while the phycoerythrin genes were only found in P. raciborskii PMC 877.14, Nostoc sp. PMC 881.14, Calothrix sp. PMC 884.14, and Pseudo-chroococcus couteii PMC 885.14. Genes for the yellow-brown pigment scytonemin were detected in the genomes of PMC 881.14, Aliinostoc sp. PMC 882.14, and PMC 884.14. All the carotenoids biosynthetic genes were identified in Laspinema sp. PMC 878.14, L. martensiana PMC 880.14, Aliinostoc sp. PMC 882.14, L. boryana PMC 883.14, and Calothrix sp. PMC 884.14. P. raciborskii PMC 877.14 lacked the crtO gene, suggesting that the strain could not produce echinenone and ketocarotenoid derivatives. The $c r t G$ gene was not detected in PMC 877.14, PMC 879.14, PMC 881.14, or PMC 885.14, which means that the strains do not have the ability to produce the hydroxylated carotenoids caloxanthin and nostoxanthin, or the myxoxanthophyll 2-hydroxymyxol 2'-methylpentoside.

Spectrophotometric analysis and HPLC were used to confirm pigment production (Table 4). Phycoerythrin was detected in the four strains in which the biosynthetic genes were identified. The concentration of phycoerythrin in P. raciborskii PMC 877.14 was $33.3 \mu \mathrm{g} \cdot \mathrm{mg}^{-1}$ (dried weight, DW) compared to $9.9 \mu \mathrm{g} \cdot \mathrm{mg}^{-1} \mathrm{DW}$ for Calothrix sp. PMC 884.14, $3.3 \mu \mathrm{g} \cdot \mathrm{mg}^{-1} \mathrm{DW}$ for P. couteii PMC 885.14 and $2.8 \mu \mathrm{g} \cdot \mathrm{mg}^{-1} \mathrm{DW}$ for Nostoc sp. PMC 881.14. The highest concentration of phycocyanin was extracted from $P$. raciborskii at $32.5 \mu \mathrm{g} \cdot \mathrm{mg}^{-1} \mathrm{DW}$ followed by L. boryana at $24.9 \mu \mathrm{g} \cdot \mathrm{mg}^{-1} \mathrm{DW}$ and Aliinostoc sp. at $\left.21.3 \mu \mathrm{g} \cdot \mathrm{mg}^{-1} \mathrm{DW}\right)$. The phycocyanin concentration in extracts of the other strains ranged from $18.4 \mu \mathrm{g} \cdot \mathrm{mg}^{-1} \mathrm{DW}$ in Laspinema sp. to $3.5 \mu \mathrm{g} \cdot \mathrm{mg}^{-1} \mathrm{DW}$ in Pseudo-chroococcus couteii. The largest allophycocyanin producers were Aliinostoc sp. and L. boryana, with 15.6 and $15.2 \mu \mathrm{g} \cdot \mathrm{mg}^{-1} \mathrm{DW}$ extracted, respectively. The allophycocyanin concentration in extracts of the other strains was lower, ranging between $7.9 \mu \mathrm{g} \cdot \mathrm{mg}^{-1} \mathrm{DW}$ for P. raciborskii and $2.7 \mu \mathrm{g} \cdot \mathrm{mg}^{-1} \mathrm{DW}$ for the $P$. couteii strain.

The amount of chlorophylls extracted was also quite variable among the different strains. The largest amount, $35.2 \mu \mathrm{g} \cdot \mathrm{mg}^{-1} \mathrm{DW}$, was extracted from P. raciborskii, while the lowest was from Nostoc sp. PMC 881.14 at $1.5 \mu \mathrm{g} \cdot \mathrm{mg}^{-1} \mathrm{DW}$.

Three different carotenoids were detected in the nine extracts. $\beta$-carotene was identified in all the strains, with concentrations ranging from $3.65 \mu \mathrm{g} \cdot \mathrm{mg}^{-1} \mathrm{DW}$ for P. raciborskii to $0.46 \mu \mathrm{g} \cdot \mathrm{mg}^{-1} \mathrm{DW}$ for Calothrix sp. and L. martensiana. Zeaxanthin was detected in extracts of $P$. raciborskii, Laspinema sp., M. vaginatus, L. martensiana, Aliinostoc sp., L. boryana, and $P$. couteii. Myxoxanthophyll-like pigments were found in six strains, but not in M. vaginatus, L. boryana, and P. couteii.

\subsection{Specialized Metabolites}

Following the analysis of the nine assembled genomes, 124 specialized metabolite biosynthetic gene clusters (BGCs) were retrieved (Table 5 and Tables S1-S9). The numbers of BGCs per strain varied from 7 to 27. Among these 124 BGCs, only 31 were correctly predicted to have the molecule produced by the cluster, representing $24.4 \%$ reliable BGC annotation (Table 5, "Identified Clusters" column). The largest number of annotations was obtained for Aliinostoc sp. PMC 882.14 and Calothrix sp. PMC 884.14, in which the production of six and five metabolites, respectively, was accurately predicted. Among the nine strains, those belonging to the Nostocales order have been shown to present the highest number of BGCs compared to other strains (Table 5). This observation is consistent with the work of Shih and co-workers who showed that heterocytic cyanobacteria tend to exhibit a higher number of BGCs [7]. Automatic annotations accurately predicted the phytoene biosynthetic pathway in all nine cyanobacterial strains, and the pathways of the mycosporine-like amino acids shinorine and mycosporine-glycine for Aliinostoc sp. PMC 882.14 and Calothrix sp. PMC 884.14. The other BGCs exhibited mostly inaccurate predictions (see Tables S1-S9 for automatic prediction results and detailed organization of the BGCs). 
Table 4. Pigment composition (mean in $\mu \mathrm{g} \cdot \mathrm{mg}^{-1} \mathrm{DW}$ ) of nine cyanobacteria isolated from Balaruc's thermal mud.

\begin{tabular}{|c|c|c|c|c|c|c|c|c|c|c|}
\hline Pigments & & $\begin{array}{l}\text { P. raciborskii } \\
\text { PMC 877.14 }\end{array}$ & $\begin{array}{l}\text { Laspinema sp. } \\
\text { PMC 878.14 }\end{array}$ & $\begin{array}{c}\text { M. vaginatus } \\
\text { PMC 879.14 }\end{array}$ & $\begin{array}{l}\text { L. martensiana } \\
\text { PMC 880.14 }\end{array}$ & $\begin{array}{c}\text { Nostoc sp. } \\
\text { PMC 881.14 }\end{array}$ & $\begin{array}{c}\text { Aliinostoc sp. } \\
\text { PMC 882.14 }\end{array}$ & $\begin{array}{c}\text { L. boryana } \\
\text { PMC 883.14 }\end{array}$ & $\begin{array}{l}\text { Calothrix sp. } \\
\text { PMC 884.14 }\end{array}$ & $\begin{array}{c}\text { P. couteii } \\
\text { PMC } 885.14\end{array}$ \\
\hline \multirow{3}{*}{ Carotenoids } & Zeaxanthin & 1.72 & 0.38 & 0.43 & 0.11 & 0.00 & 0.01 & 0.22 & 0.00 & 0.29 \\
\hline & Myxoxanthophyll-like & 0.44 & 0.28 & 0.00 & 0.12 & 0.03 & 0.32 & 0.00 & 0.21 & 0.00 \\
\hline & $\beta$-Carotene & 3.65 & 1.43 & 1.06 & 0.46 & 0.15 & 1.29 & 1.31 & 0.46 & 0.78 \\
\hline \multirow{3}{*}{ Chlorophylls } & Bacteriochlorophyll a & 0.54 & 0.04 & 0.12 & 0.04 & 0.06 & 0.08 & 0.07 & 0.07 & 0.02 \\
\hline & Chlorophyll a & 35.2 & 9.8 & 11.2 & 4.9 & 1.5 & 12.3 & 17.1 & 9.7 & 6.7 \\
\hline & Phaeophytin a & 0.00 & 0.09 & 0.07 & 0.02 & 0.01 & 0.00 & 0.09 & 0.04 & 0.00 \\
\hline \multirow{3}{*}{ Phycobiliproteins } & Phycocyanin & $32.5 \pm 12.8$ & $18.4 \pm 0.2$ & $12.2 \pm 2.1$ & $6.1 \pm 0.5$ & $2.1 \pm 0.1$ & $21.3 \pm 4.7$ & $24.9 \pm 4.4$ & $9.9 \pm 0.4$ & $3.5 \pm 0.1$ \\
\hline & Allophycocyanin & $7.9 \pm 3.5$ & $6.6 \pm 0.5$ & $5.8 \pm 1.1$ & $3.7 \pm 0.3$ & $1.5 \pm 0.2$ & $15.6 \pm 3.5$ & $15.2 \pm 3.8$ & $6.7 \pm 0.3$ & $2.7 \pm 0.2$ \\
\hline & Phycoerythrin & $33.3 \pm 12.1$ & 0.00 & 0.00 & 0.00 & $2.8 \pm 0.2$ & 0.00 & 0.00 & $9.9 \pm 0.3$ & $3.3 \pm 0.1$ \\
\hline
\end{tabular}

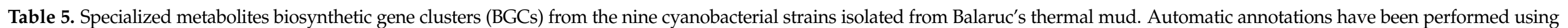

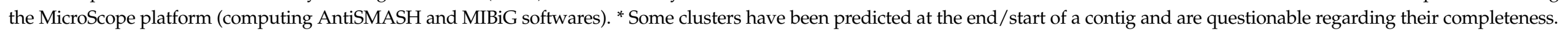

\begin{tabular}{|c|c|c|c|c|c|c|}
\hline Genus/Species & Strain & $\mathrm{Nb}$ of Clusters Predicted & Identified Clusters & Reported Activity & Unknown/Homologous Cluster & Unknown/Unknown Cluster \\
\hline P. raciborskii & PMC 877.14 & 7 & Phytoene or derivative & Antioxidant & 1 & 5 \\
\hline Laspinema sp. & PMC 878.14 & 7 & Phytoene or derivative & Antioxidant & 5 & 0 \\
\hline M. vaginatus & PMC 879.14 & 7 & $\begin{array}{l}\text { Heterocyclic cyanobactin } \\
\text { Phytoene or derivative } \\
\text { Phytoene or derivative }\end{array}$ & $\begin{array}{l}\text { Antioxidant } \\
\text { Antioxidant }\end{array}$ & 3 & 3 \\
\hline L. martensiana & PMC 880.14 & 9 & $\begin{array}{l}\text { Squalene } \\
\text { Schizokinen-like }\end{array}$ & $\begin{array}{l}\text { Antioxidant } \\
\text { Iron-chelating activity }\end{array}$ & 5 & 1 \\
\hline Nostoc sp. & PMC 881.14 & 20 * & $\begin{array}{l}\text { Phytoene or derivative }(2 \times) \\
\text { Heterocyst glycolipid } \\
\text { Shinorine-like } \\
\text { Microginin-like }\end{array}$ & $\begin{array}{l}\text { Antioxidant } \\
\text { n.d. } \\
\text { Antioxidant } \\
\text { ACE inhibition; no cytotoxic }\end{array}$ & 7 & 10 \\
\hline Aliinostoc sp. & PMC 882.14 & 21 & $\begin{array}{l}\text { Amycomicin-like } \\
\text { Phytoene or derivative }(2 \times) \\
\text { Heterocyst glycolipid } \\
\text { Microviridin-like }\end{array}$ & $\begin{array}{l}\text { Antibiotic } \\
\text { Antioxidant } \\
\text { n.d. } \\
\text { Protease inhibitor }\end{array}$ & 6 & 8 \\
\hline L. boryana & PMC 883.14 & 16 & Phytoene or derivative $(5 \times)$ & Antioxidant & 8 & 3 \\
\hline Calothrix sp. & PMC 884.14 & 27 & $\begin{array}{l}\text { Cyanobactin } \\
\text { Mycosporine-glycine-like } \\
\text { Cylindrocyclophane-like } \\
\text { Phytoene/Lycopene or } \\
\text { derivative }(3 \times) \\
\text { Heterocyst glycolipid }\end{array}$ & $\begin{array}{l}\text { Cytotoxic } \\
\text { Antioxidant } \\
\text { Cytotoxic; antibacterial } \\
\text { Antioxidant } \\
\text { n.d. }\end{array}$ & 14 & 6 \\
\hline
\end{tabular}


Expert manual annotation also allowed the identification of a schizokinen-like biosynthetic cluster in L. martensiana PMC 880.14, from one BGC automatically annotated as siderophore. Heterocyst glycolipid BGCs were identified in the three Nostocales strains (Nostoc sp. PMC 881.14, Aliinostoc sp. PMC 882.14 and Calothrix sp. PMC 884.14). The BGC of ribosomally synthesized peptides with post-translational modifications (RiPPs) of cyanobactins was identified in two strains: Laspinema sp. PMC 878.14 and Calothrix sp. PMC 884.14. Another RiPP, microviridin, was characterized from Aliinostoc sp. PMC 882.14, and shared strong homology with the microviridin $\mathrm{K}$ biosynthetic gene cluster. The type I polyketide synthetase (PKS) of amycomicin has been proposed for a PKS gene cluster from Aliinostoc sp. PMC 882.14. The cylindrocyclophane-like gene cluster has been identified from an NRPS cluster in Calothrix sp. PMC 884.14. Our manual expert annotation also allowed the identification of a microginin BGC from a hybrid NRPS-PKS automatically annotated as the puwainaphycin cluster in Aliinostoc sp. PMC 882.14. No cyanotoxin (microcystins, anatoxins, cylindrospermopsins, saxitoxins, etc.) gene clusters were identified in any of the strains. Among the 93 unknown clusters, 51 showed homologous matches with clusters identified in other strains, without characterization of the molecule synthesized, while 42 were fully uncharacterized.

The metabolites putatively identified by the genomic approach were also subjected to LC-MS/MS analysis. A dataset of 3986 analytes was obtained, with their respective intensity in the different extracts (water or methanol) and their respective fragmentation pattern. The molecular network assembled from the analyzed MS/MS is presented in Figure 1 and Figure S2. This type of representation makes it possible to group together analytes in clusters that sharing similarities in their fragmentation spectra and therefore have structural similarities. In these figures, one node represents one analyte with its own mass and fragmentation spectra. The molecular networking performed with the GNPS algorithm allowed us to group 1155 analytes (29\%) into 128 clusters containing at least three different analytes. The remaining analytes were classified in pairs or singletons. In Figure 1, nodes have been colored according to the strain from which they were identified. Figure S2 represents the same analysis while nodes have been colored according to their original fraction (water or methanol). Most of the analytes were observed in several strain extracts (Figure 1A) while some were identified exclusively in a single strain (Figure 1B). The same pattern was identified at the cluster level, with several clusters containing multi-species analytes (Figure 1C) and almost 50 strain-specific clusters (Figure 1D). Comparisons with public and in-house spectral MS/MS databases together with the molecular formula database of more than 2100 cyanobacterial metabolites (CyanoMetDB) allowed the prospective annotation of 193 of those analytes (Figure 1 and Table S10). Primary metabolites have most often been identified, including diverse dipeptides, ribonucleosides, and cofactors (NAD+), as well as glycerolipids, polysaccharides, lysophosphatidylcholines and lysophosphoethanolamines. Several mycosporine-like amino acids (MAAs) were also characterized with specific matches to shinorine, mycosporine-glycine and palythine. A few specialized cyanobacterial metabolites were identified, notably aeruginosin-like compounds, anabaenolysins, largamides, microphycins, microviridins, and microginins. According to the propagation principle, one would expect that analytes from the same clusters should belong to the same chemical family.

The annotation details for the targeted list of metabolites of interest from the nine cyanobacterial strains, selected for their potential bioactivities, are given in Table 6. Cyanobacterial pigments are well known for their antioxidant and/or anti-inflammatory properties, and several metabolites with potentially similar bioactivities were identified. Several different MAAs, known to be antioxidant metabolites, were detected in seven strains. Mycosporine-glycine was annotated for PMC 882.14 and PMC 884.14. Shinorine has been detected in Aliinostoc sp. PMC 882.14, implying a remarkable antioxidant potential for these two cyanobacteria. One congener of the anti-inflammatory aeruginosin family, aeruginosin TR642, was also annotated in L. boryana PMC 883.14, highlighting the anti-inflammatory potential of this strain. 


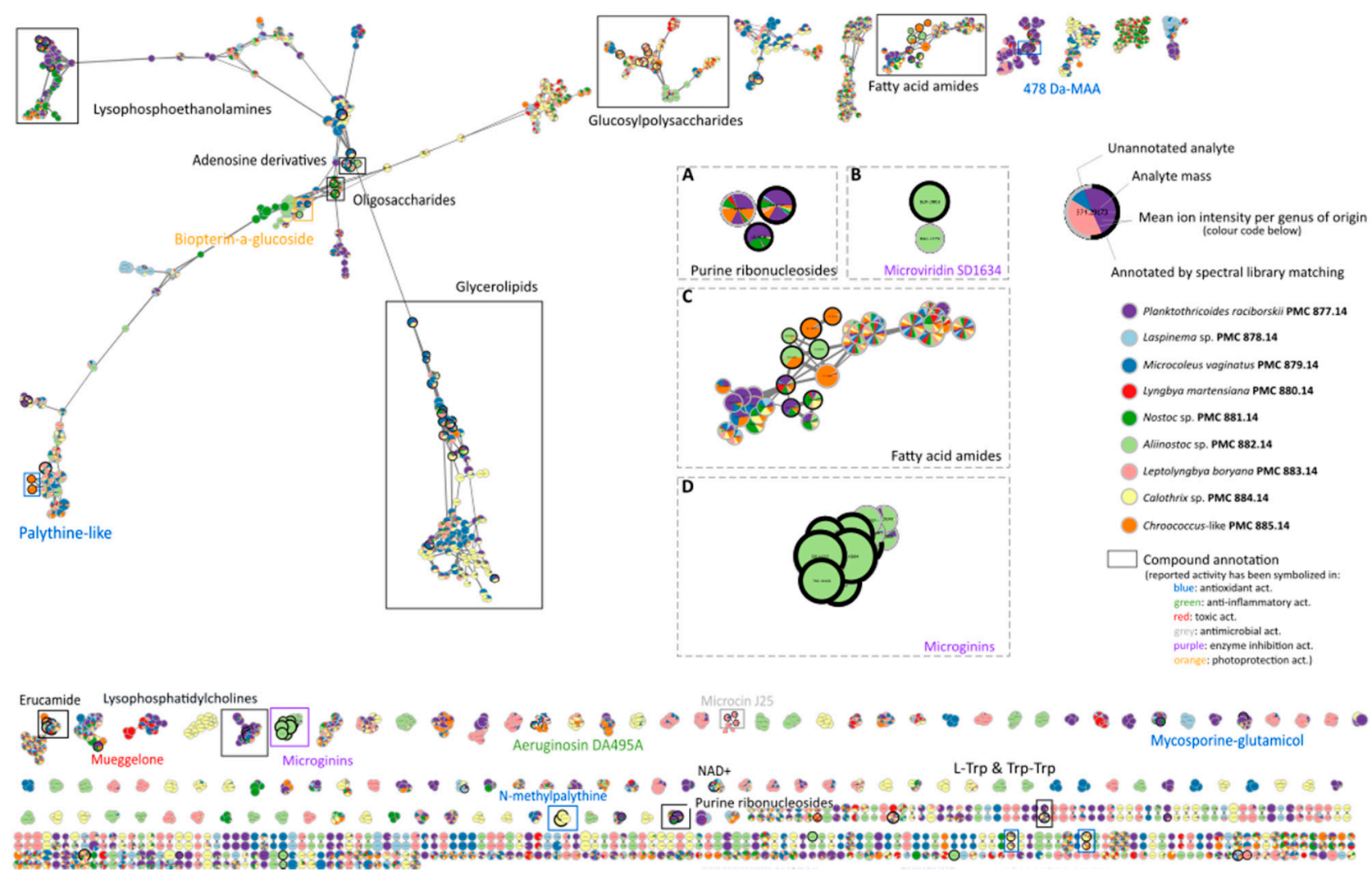

Figure 1. Molecular network of the metabolites produced by nine cyanobacteria isolated from Balaruc's thermal mud. Annotations obtained by untargeted analysis are figured inboxes. Nodes have been colored according to the strain in which they have been identified. (A) Purine ribonucleosides cluster; (B) Microviridins cluster; (C) Fatty acid amides cluster; (D) Microginins cluster.

\subsection{Bioactivity Assessment}

Specific bioassays were done to determine the antioxidant, anti-inflammatory and wound healing activities of the cyanobacterial extracts. Both aqueous and methanol extracts were tested at concentrations of $1,5,10$, and $50 \mu \mathrm{g} \cdot \mathrm{mL}^{-1}$ (Table 7).

Antioxidant activity was evaluated by measuring the effect of crude extracts on the amount of the reactive oxygen species, nitric oxide (NO) produced by the murine macrophage cell line, RAW 264.7, subjected to oxidative stress by exposure to lipopolysaccharides (LPS). NO is evolved during normal oxidative metabolism, but an excess of free radicals can cause cell damage and overwhelm protective antioxidant enzymes. A positive antioxidant effect was recorded when an extract reduced the amount of NO produced comparable to the negative control. No significant inhibition of NO formation was seen at the extract concentrations tested. A slight increase in NO production $(+20 \%)$ was observed for the aqueous extract of Nostoc sp. PMC 881.14 at $50 \mu \mathrm{g} \cdot \mathrm{mL}^{-1}$ (Table 7), suggesting that this extract might have pro-oxidant capabilities. 
Table 6. Potential antioxidant and anti-inflammatory compounds identified by HPLC-DAD or LC-MS/MS in the extracts of the nine cyanobacteria strains isolated from Balaruc's thermal mud. MAAs: Mycosporine-like Amino Acids. "+" and "-" indicate the detection or not of the gene clusters.

\begin{tabular}{|c|c|c|c|c|c|c|c|c|c|c|}
\hline Class & Compound & $\begin{array}{l}\text { P. raciborskii } \\
\text { PMC 877.14 }\end{array}$ & $\begin{array}{l}\text { Laspinema sp. } \\
\text { PMC 878.14 }\end{array}$ & $\begin{array}{l}\text { M. vaginatus } \\
\text { PMC 879.14 }\end{array}$ & $\begin{array}{l}\text { L. martensiana } \\
\text { PMC 880.14 }\end{array}$ & $\begin{array}{l}\text { Nostoc sp. } \\
\text { PMC 881.14 }\end{array}$ & $\begin{array}{l}\text { Aliinostoc sp. } \\
\text { PMC 882.14 }\end{array}$ & $\begin{array}{l}\text { L. boryana } \\
\text { PMC 883.14 }\end{array}$ & $\begin{array}{l}\text { Calothrix sp. } \\
\text { PMC 884.14 }\end{array}$ & $\begin{array}{c}\text { P. couteii } \\
\text { PMC } 885.14\end{array}$ \\
\hline \multirow{4}{*}{$\begin{array}{l}\text { MAAs } \\
\text { (antioxidant) }\end{array}$} & Mycosporine-glycine & - & - & - & - & - & + & - & + & - \\
\hline & Mycosporine-ornithine & - & - & - & - & + & - & - & - & - \\
\hline & Nostoc-756 & - & - & - & - & + & - & - & - & - \\
\hline & Shinorine & - & - & - & - & - & + & - & - & - \\
\hline \multirow{4}{*}{$\begin{array}{l}\text { Carotenoids } \\
\text { (antioxidant) }\end{array}$} & Canthaxanthin & - & - & + & + & - & + & + & + & + \\
\hline & Myxoxanthophyll-like & + & + & - & + & - & + & - & + & - \\
\hline & Zeaxanthin & + & + & + & + & - & - & + & - & + \\
\hline & $\beta$-carotene & + & + & + & + & + & + & + & + & + \\
\hline \multirow{2}{*}{$\begin{array}{l}\text { Chlorophylls } \\
\text { (antioxidant) }\end{array}$} & Chlorophyll a & + & + & + & + & + & + & + & + & + \\
\hline & Bacteriochlorophyll a & + & - & + & - & - & - & - & - & - \\
\hline \multirow{3}{*}{$\begin{array}{l}\text { Phycobiliproteins } \\
\text { (antioxidant) }\end{array}$} & $\begin{array}{l}\text { Phycocyanin } \\
\text { (Anti-inflammatory) }\end{array}$ & + & + & + & + & + & + & + & + & + \\
\hline & Allophycocyanin & + & + & + & + & + & + & + & + & + \\
\hline & Phycoerythrin & + & - & - & - & + & - & - & + & + \\
\hline \multirow[t]{3}{*}{$\begin{array}{l}\text { Aeruginosins } \\
\text { (anti-inflammatory) }\end{array}$} & Aeruginosin TR642 & - & - & - & - & - & - & + & - & - \\
\hline & Antioxidant & 8 & 6 & 7 & 7 & 7 & 8 & 6 & 9 & 8 \\
\hline & Anti-inflammatory & 1 & 1 & 1 & 1 & 1 & 1 & 2 & 1 & 1 \\
\hline
\end{tabular}




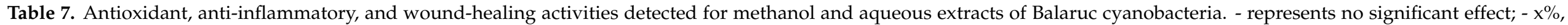
significant inhibiting effect percentage; $+x \%$, significant increasing effect percentage.

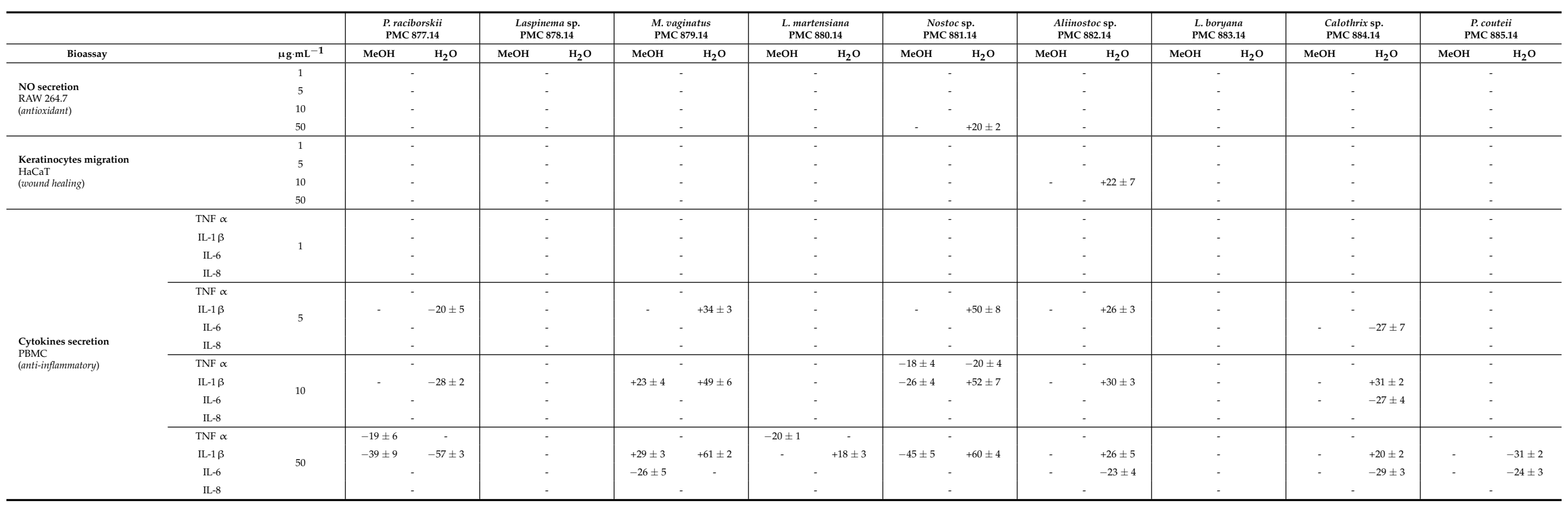


The anti-inflammatory properties have been evaluated by measuring specific cytokine secretion by immune cells (PBMCs) exposed to LPS. The secretion of four cytokines, involved in upregulation of the inflammatory response, were assayed: TNF- $\alpha$, Il- $1 \beta$, IL-6, and IL-8 $[42,43]$. Several aqueous or methanol extracts showed effects on cytokine release, with the majority occurring at the higher concentrations of $10 \mu \mathrm{g} \cdot \mathrm{mL}^{-1} \mathrm{DW}$ and $50 \mu \mathrm{g} \cdot \mathrm{mL}^{-1}$ DW (Table 7). Some of the responses were proinflammatory with an increase in cytokine production, while others showed anti-inflammatory activity and decreased cytokine secretion. Distinct dissimilarities in the cytokine responses were observed in several strains, notably for the aqueous extracts of Aliinostoc sp. PMC 882.14 that enhanced IL- $1 \beta$ secretion and inhibited Il-6 secretion at $50 \mu \mathrm{g} \cdot \mathrm{mL}^{-1}$. The methanol extract of $P$. raciborskii PMC 877.14 and the aqueous extract of $P$. couteii PMC 885.14 had the best anti-inflammatory properties as they each simultaneously inhibited the release of two cytokines involved in proinflammatory responses-TNF- $\alpha$ and Il- $1 \beta$, and Il- $1 \beta$ and Il- 6 respectively. The greatest inhibition of cytokine secretion was observed with the aqueous extract of PMC 877.14 with a $57 \%$ decrease of IL- $1 \beta$, compared to the negative control.

The wound-healing activity of the crude cyanobacterial extracts was also evaluated by monitoring the cellular migration of the keratinocyte cell line, $\mathrm{HaCaT}$, for $48 \mathrm{~h}$ following injury to the monolayer. The aqueous extract of Aliinostoc sp. PMC 882.14 at $10 \mu \mathrm{g} \cdot \mathrm{mL}^{-1}$ slightly increased keratinocyte migration by $22 \% \pm 7$ compared to the negative DMSO control, suggesting a beneficial effect of this extract on wound healing (Table 7).

Cell viability was determined on the three cell types used in the bioassays: murine macrophages (RAW 264.7), human keratinocytes (HaCaT), and peripheral blood mononuclear cells (PBMC) (Table S11). This assay has allowed us to assess the viability of the respective cell types used in the bioassays, as well as to evaluate the potential cytotoxicity of the crude extract on these different cell types. No loss of viability of HaCaT human cell line and human PBMC was observed. Murine macrophages RAW 264.7 were apparently more sensitive and showed a slight loss of viability.

\section{Discussion}

\subsection{Genome Quality, Genome Mining, and Molecular Network Analysis}

Application of the genome mining approach led to the identification and characterization of biosynthetic gene clusters (BGCs) for natural products. This approach requires high-quality genomic data to confidently annotate the BGCs and excludes doubtful affiliations, especially in the context of genome sequencing and assembly with meta-genomes generated from nonaxenic strains [44]. The median size of the nine cyanobacterial genomes was $7.3 \mathrm{Mb}$, which is higher than the $5.6 \mathrm{Mb}$ median size of the cyanobacterial genomes referenced in GenBank [45]. However, Alvarenga and co-workers [46] showed that the latter value was biased by the high number of Prochlorococcus genomes available wherein the size was $<3 \mathrm{Mb}$. The GC percentage of our nine genomes (42\%) was comparable to reference cyanobacterial genomes, already available on public database such as NCBI's.

The high completeness scores (>97\%) obtained for the nine genome assemblies led us to conclude that the draft genomes for all strains were nearly, if not totally, complete. The low contamination score $(<1.4 \%)$ indicates that our double binning strategy, which was based on both BLAST and K-mer contig clustering, gives reliable results for obtaining uncontaminated cyanobacterial genomes from nonaxenic monoclonal cultures. According to Parks and co-workers, who developed the CheckM tool, the values of these two scores indicate high quality for the nine cyanobacterial genome assemblies obtained from metagenomic data [47]. Automated tools, such as antiSMASH, together with experts' participation, allowed the annotation of $24 \%$ of the 124 identified BGCs. BGCs without annotations were considered orphan gene clusters for which the synthesized metabolite was unknown. However, 52\% of these orphan clusters had high homologies with other orphan clusters already observed in other cyanobacteria. This opens up the possibility of global comparative studies of these different strains characterizing their metabolites, as was done for the cyanobactin biosynthesis pathway [48]. 


\subsection{Cytotoxic Properties}

We investigated the potential cytotoxicity of the different extracts on the RAW 264.7, $\mathrm{HaCat}$ cell lines and on human PBMCs. No significant cytotoxicity was detected on the two last cell types while a slight loss of viability was observed on the more sensitive murine cell line (RAW 264.7) with some extracts. Overall, no cyanotoxins, such as microcystins, anatoxins, saxitoxins, cylindrospermopsins, or nodularins, were identified in the crude extracts and no cyanotoxin BGCs were detected in the nine genome assemblies, suggesting that the nine strains did not present a toxicity risk and are suitable for therapeutic purposes. However, two potential cyanobactin BGCs were identified in Laspinema sp. PMC 878.14 and Calothrix sp. PMC 884.14. The two clusters represented one gene encoding a heterocyclase enzyme. This may mean that the cyanobactins produced by these strains belong to the group of heterocyclized cyanobactins, which includes patellamides, tenuecyclamides, trichamide, aeruginosamide, and others [11] with potentially cytotoxic activities $[49,50]$. However, not all cyanobactins exhibit cytotoxic activity and no known cyanobactin compounds were identified in crude extracts of the two strains.

\subsection{Antioxidant Properties}

Antioxidants have been studied for many years as novel treatments for diseases such as atherosclerosis, osteoarthritis, and neurodegenerative disorders and have been generally recognized as compounds that promote well-being [51]. Pigmented compounds are produced by all cyanobacteria and have shown potentially beneficial properties [52-54]. Biosynthetic genes for phycocyanins and chlorophylls have been detected in the nine cyanobacteria, but their relative amounts varied considerably among the different strains. Calothrix sp. PMC 884.14, L. martensiana PMC 880.14, P. couteii PMC 885.14, and Nostoc sp. PMC 881.14 possessed a thick sheath and abundant mucilage that may have affected the pigment extraction efficiency or have biased the measurement of pigment mass by increasing the apparent lyophilisate weight or reducing the number and volume of extracted cells. These observations are consistent with the conclusions of Finkel and co-workers who demonstrated phylogenetic difference in macromolecular composition, notably of chlorophyll $a$ [55]. Phycoerythrin genes have been identified in P. raciborskii PMC 877.14, Nostoc sp. PMC 881.14, Calothrix sp. PMC 884.14, and P. couteii PMC 885.14. Phycoerythrin was detected and quantified in these four strains and appeared to be produced constitutively. Carotenoids pathways have also been characterized in the nine assemblies according to the pathways proposed by Kosourov et al. (2016). These authors described sixteen genes coding for enzymes involved in the synthesis of hydroxylated carotenoids, ketocarotenoids, echinenone, and myxoxanthophylls [56]. Of the known carotenoids described in cyanobacteria $[57,58]$, only four have been identified in this study: zeaxanthin, canthaxanthin, myxoxanthophyll-like molecules, and $\beta$-carotene (Table 4). Only this last has been detected in all nine strains. Regarding the others, several reasons could explain their non-detection. Some strains did not possess all the genes necessary for the synthesis of certain carotenoids. This is the case for P. raciborskii PMC 877.14 which lacks the $c r t O$ gene encoding a $\beta$-carotene ketolase required for canthaxanthin synthesis. This enzyme catalyzes the transformation of $\beta$-carotene into echinenone and echinenone into canthaxanthin; thus, this strain is unable to produce canthaxanthin. For the strains possessing all carotenoid biosynthetic genes but appearing to lack carotenoid, it is possible that the amount extracted from the strains is below the detection limit or that some regulatory processes for intermediary products in the linear pathway are inhibiting carotenoid biosynthesis.

Specialized metabolites with potential antioxidant properties have also been detected in the cyanobacterial extracts. Mycosporine-like amino acids (MAAs) are a family of small metabolites identified in fungi, plants, and bacteria, including cyanobacteria, and showing antioxidant and photo-protective activities [59]. BGCs for MAAs have been characterized by automatic annotation tools from Aliinostoc sp. PMC 882.14 and Calothrix sp. PMC 884.14. Both BGCs contained one demethyl-4-deoxygadusol synthase, one Omethyltransferase, one ATP-grasp domain and one NRPS module described for synthesis of 
MAAs $[60,61]$. Both strains produced mycosporine-glycine, the first molecule synthesized from the 4-deoxygadusol precursor. Only PMC 882.14 had the ability to produce shinorine, as this metabolite requires serine incorporation brought about by one adenylation domain. Manual exploration of the Nostoc sp. PMC 881.14 genome identified a MAAs gene cluster containing one D-Ala-D-Ala ligase replacing the NRPS gene. This gene cluster organization was similar to that described for Cylindrospermum stagnale PCC 7417 [61,62]. While 4deoxygadusol (4-DG) in PMC 881.14 was synthesized from the shikimate pathway instead of the pentose phosphate pathway, mycosporine-ornithine was detected as in PCC 7417.

Unexpectedly, no effects on nitric oxide production were observed for any of the strains despite the antioxidant potential of their pigments and specialized metabolites (Table 6). This absence of effect could be due to low concentration of these pigment molecules in the crude extracts or the potential antagonistic effect of specific inhibitors. Cyanobacteria could also produce oxidative compounds as found for the Nostoc sp. PMC 881.14 aqueous extract, in which the cellular oxidative potential increased $20 \%$. This increased NO formation could be caused by the lipopolysaccharide (LPS) content of this strain, even though cyanobacterial LPS is said to be a weak inducer of oxidant activity compared to other Gram-negative bacteria $[63,64]$.

\subsection{Wound-Healing Properties}

Cell migration is involved in many diseases such as for metastasis and the development of atherosclerosis and arthritis, but is also necessary for normal physiological processes like keratinocyte migration in wound healing or the translocation of leukocytes in the inflammatory response and immune functions [65,66]. The Aliinostoc sp. PMC 882.14 extract stimulated slightly keratinocyte migration on the HaCaT cell line. Several cyanobacterial extracts have been studied in recent years for their potential wound-healing effects $[67,68]$, but the mechanism of action of most of these compounds remains unclear. The aqueous extract of Aliinostoc sp. PMC 882.14 exhibited a wound healing effect, but did not promote Il-6 secretion. We hypothesized that this mechanism is different from the process observed in Synechococcus elongatus PMC 7942 [69], but could be more similar to pathways described for apratyramide, as it induced the secretion of growth factor [70]. Apratyramide, isolated from Moorea bouillonii, is a linear depsipeptide of five residues with two terminal N-methylated tyrosines. This terminal organization is quite similar to that of the microginin family [71] and a microginin BGC was identified and several congeners characterized by molecular networking in Aliinostoc sp. PMC 882.14 (Figure 1) suggesting the possibility that microginins could be involved in the observed wound healing activity as they share the same tyrosine pattern as apratyramide. Microginins have also been described as protease inhibitors [72-74] and angiotensin converting enzyme inhibitors $[75,76]$. Phlebitis and other vascular diseases have been cured in the thermal baths of Balaruc-les-Bains since ancient times, and the microginins produced by Aliinostoc sp. PMC 882.14 could be involved in these therapeutic properties.

\subsection{Anti-Inflammatory Properties}

Inflammation is a normal immune process involving a complex network of cells, regulatory pathways and pro- and anti-inflammatory molecular activities to balance the immune response. Defects in immunoregulation can lead to chronic inflammatory diseases such as rheumatoid arthritis, psoriasis, multiple sclerosis, and others [77,78]. Proinflammatory cytokine responses to the crude extracts showed different profiles depending on the strain tested (Table 7). Some extracts showed complex patterns with increasing secretion of one cytokine concomitant with decreased release of another cytokine, making it difficult to draw conclusions about their respective global anti-inflammatory activity. Nevertheless, three strains showed promising anti-inflammatory effects by inhibiting the production of one or more cytokines. Both methanol and water extract of P. raciborskii PMC 877.14 showed decreased levels of TNF- $\alpha$ and Il- $1 \beta$. As PMC 877.14 is the most important phycocyanin producer of the nine strains from Balaruc-les-Bains, anti-inflammatory properties of the 
aqueous extract could be attributed to the phycobilin pigment. The aqueous extract of P. couteii PMC 885.14 inhibited the secretion of Il-1 $\beta$ and Il-6. As only low levels of phycocyanin were extracted from this strain, it is likely that another molecule is responsible for this activity. In a recent paper on the therapeutic properties of Phormidium sp. ETS05 from thermal mud in Italy, Zampieri et al. reported that hydrosoluble exopolysaccharides demonstrated anti-inflammatory properties without toxicity [23]. The same macromolecules could be responsible for the anti-inflammatory properties of Pseudo-chroococcus couteii, which possesses a thick polysaccharide sheath [27].

Scytonemin BGC has been detected in PMC 881.14. Scytonemin is a lipid-soluble, yellow-brown pigment with anti-inflammatory activity [79]. Unfortunately, we were not able to detect scytonemin or its congeners by our metabolomic analysis and this absence, or non-detection, has been attributed to unfavorable culture conditions for scytonemin production, as scytonemin synthesis has been shown to be upregulated by UV-A exposure $[60,79]$. As scytonemin could not be responsible for the anti-inflammatory properties of methanol extracts of PMC 881.14 and PMC 877.14, we hypothesized that other molecules must be responsible for the anti-inflammatory properties. Potential candidates could be lipid-derived products as they represent the biggest cluster in our network. This explanation is supported by research from Bruno et al. (2005) who described the anti-inflammatory activities of several galactosyl-diacyl-glycerol compounds [80].

\subsection{General Comments}

The various results obtained in the course of this study open up interesting perspectives in different fields of application and provide insights into the therapeutic mechanisms of thermal mud. In fact, it has been shown that both the "inorganic" and "organic" parts of the peloids confer therapeutic properties to thermal cures [81,82]. To go further in understanding these mechanisms for the thermal mud of Balaruc-les-Bains specifically, it would be interesting to study the metabolome of the strains and their bioactivities under other conditions, including co-culture experiments with the mud/thermal water mixture. This experiment would make it possible to mimic the natural maturation conditions of the peloid and would make it possible to study the whole metabolome and bioactivities of the thermal mud flora as has been done for other thermal baths [83,84]. Moreover, several studies have shown that the metabolome of cyanobacteria varies under co-culture conditions $[85,86]$, allowing the hypothesis that bioactivities (including the antioxidant activity) could be enhance by synergistic interactions.

While the cyanobacterial extracts did not show cytotoxicity to the cell's types tested, it might be advisable that we tested them against several other cell lines. Because of their transporters, some cell lines could be more sensible to cyanobacterial peptides, which need to be transport into the cell to be toxic. This is the case, for example, of microcystins, which are internalized by liver cells thanks to transporters specific to certain cellular tissues [87].

Beyond the applications sought for balneology, the metabolites identified within the framework of this study could potentially be used in other fields such as cosmetics or pharmaceuticals. It would therefore be interesting to go further in the characterization of the structures and the bioactivities of the whole metabolites. Indeed, cytotoxic compounds, such as cyanobactins or cylindrocyclophanes, have to be investigated in order to develop anticancer drugs when protease-inhibiting molecules (such as microviridins and microginins) can be used in the treatment of vascular diseases, hypertension, or infectious diseases [4].

For future experiments, it could be interesting to purify certain compounds and characterize their structures by HPLC and NMR spectrometry, to characterize their individual activities by other bioassays (other antioxidant tests, protease inhibition tests) and to follow their production kinetics during the different growth phases of the cyanobacteria strains of interest. 


\section{Conclusions}

Cyanobacteria are prolific producers of natural compounds exhibiting a wide range of chemical structures and activities [4,5]. Although their biological functions remain largely unknown, some compounds have demonstrated their usefulness in pharmacology such as dolastatin 10 for the treatment of lymphoma in Hodgkin's disease [15,88-90]. Here, we investigated the potential beneficial activities of nine cyanobacteria isolated from the thermal mud of Balaruc-les-Bains, France, in terms of the production of antioxidant and/or anti-inflammatory compounds using genomic, metabolomic, and bioactivity analyses. With only $24 \%$ of the biosynthetic gene clusters annotated, Balaruc's cyanobacteria constitute a rich source of potentially valuable natural products. The nine strains, which do not express harmful cyanotoxins and did not show cytotoxicity against two human cell types, exhibited beneficial anti-inflammatory and wound-healing properties possibly arising from the identified pigments and specialized metabolites. Although no antioxidant activity was detected, strong anti-inflammatory potential was proven for Planktothricoides raciborskii PMC 877.14, Nostoc sp. PMC 881.14, and Pseudo-chroococcus couteii PMC 885.14, and a slight wound-healing function was detected in extracts from Aliinostoc sp. PMC 882.14. Antioxidant properties still need to be studied as several strains showed high production of antioxidant pigments, while our assays failed to detect activity. Nevertheless, our study shows a promising potential in further developments for Balaruc's cyanobacteria and opens avenues of future work for applications of the active biomolecules, improvement of their production, and the resolution of their mechanism of action.

Supplementary Materials: The following are available online at https:/ /www.mdpi.com/2218-273 X/11/1/28/s1: Figure S1. Consensus phylogenetic tree based on $16 \mathrm{~S}$ rRNA gene sequences; Figure S2. Molecular network (coloured by extraction methods); Tables S1-S9. BGCs description from the nine strains; Table S10. Pigment biosynthetic genes from the nine strains; Table S11. Results of the cell viability assays; Tables S12-S20. BGCs from associated heterotrophic bacteria.

Author Contributions: Conceptualization, J.D., A.R., P.V., A.K.-O., C.B., and B.M.; methodology, J.D., C.D., C.Y., and S.H. (Sahima Hamlaoui); investigation, J.D., S.H. (Sébastien Halary), T.R., and A.K.-O.; resources, C.D. and C.Y.; writing—original draft preparation, J.D., C.B., and B.M.; writing—review and editing, all authors. All authors have read and agreed to the published version of the manuscript.

Funding: This research was funded by ANRT, through a PhD grant number 2017/0633 awarded to J. Demay.

Acknowledgments: We would like to thank the UMR 7245 MCAM, Muséum National d'Histoire Naturelle, Paris, France for laboratories facilities and the Thermes de Balaruc-les-Bains for funds. The authors thank the Laboratoire d'Oceanographie de Villefranche-sur-Mer (France) for performing liposoluble pigment analysis, the Pasteur Collection of Cyanobacteria for assisting in the development of the DNA extraction process and the ChemBioFrance National Infrastructure for advices. The authors thank the anonymous referees for providing valuable suggestions that significantly improved the quality of the manuscript.

Conflicts of Interest: The authors declare no conflict of interest.

\section{References}

1. Kurmayer, R.; Deng, L.; Entfellner, E. Role of toxic and bioactive secondary metabolites in colonization and bloom formation by filamentous cyanobacteria Planktothrix. Harmful Algae 2016, 54, 69-86. [CrossRef] [PubMed]

2. Mazard, S.; Penesyan, A.; Ostrowski, M.; Paulsen, I.T.; Egan, S. Tiny Microbes with a Big Impact: The Role of Cyanobacteria and Their Metabolites in Shaping Our Future. Mar. Drugs 2016, 14, 97. [CrossRef] [PubMed]

3. Buratti, F.M.; Manganelli, M.; Vichi, S.; Stefanelli, M.; Scardala, S.; Testai, E.; Funari, E. Cyanotoxins: Producing organisms, occurrence, toxicity, mechanism of action and human health toxicological risk evaluation. Arch. Toxicol. 2017, 91, 1049-1130. [CrossRef] [PubMed]

4. Demay, J.; Bernard, C.; Reinhardt, A.; Marie, B. Natural products from cyanobacteria: Focus on beneficial activities. Mar. Drugs 2019, 17, 320. [CrossRef] [PubMed]

5. Ali Shah, S.A.; Akhter, N.; Auckloo, B.N.; Khan, I.; Lu, Y.; Wang, K.; Wu, B.; Guo, Y.W. Structural diversity, biological properties and applications of natural products from cyanobacteria. A review. Mar. Drugs 2017, 15, 354. [CrossRef] 
6. Calteau, A.; Fewer, D.P.; Latifi, A.; Coursin, T.; Laurent, T.; Jokela, J.; Kerfeld, C.A.; Sivonen, K.; Piel, J.; Gugger, M. Phylum-wide comparative genomics unravel the diversity of secondary metabolism in Cyanobacteria. BMC Genom. 2014, 15, 977. [CrossRef]

7. Shih, P.M.; Wu, D.; Latifi, A.; Axen, S.D.; Fewer, D.P.; Talla, E.; Calteau, A.; Cai, F.; Tandeau de Marsac, N.; Rippka, R.; et al. Improving the coverage of the cyanobacterial phylum using diversity-driven genome sequencing. Proc. Natl. Acad. Sci. USA 2013, 110, 1053-1058. [CrossRef]

8. Dittmann, E.; Gugger, M.; Sivonen, K.; Fewer, D.P. Natural Product Biosynthetic Diversity and Comparative Genomics of the Cyanobacteria. Trends Microbiol. 2015, 23, 642-652. [CrossRef]

9. Leao, T.; Castelão, G.; Korobeynikov, A.; Monroe, E.A.; Podell, S.; Glukhov, E.; Allen, E.E.; Gerwick, W.H.; Gerwick, L. Comparative genomics uncovers the prolific and distinctive metabolic potential of the cyanobacterial genus Moorea. Proc. Natl. Acad. Sci. USA 2017, 114, 3198-3203. [CrossRef]

10. Nivina, A.; Yuet, K.P.; Hsu, J.; Khosla, C. Evolution and Diversity of Assembly-Line Polyketide Synthases. Chem. Rev. 2019, 119, 12524-12547. [CrossRef]

11. Martins, J.; Vasconcelos, V. Cyanobactins from cyanobacteria: Current genetic and chemical state of knowledge. Mar. Drugs 2015, 13, 6910-6946. [CrossRef] [PubMed]

12. Tan, L.T. Biomedical potential of marine cyanobacteria. J. Coast. Dev. 2006, 9, 129-136.

13. Vijayakumar, S.; Menakha, M. Pharmaceutical applications of cyanobacteria-A review. J. Acute Med. 2015, 5, 15-23. [CrossRef]

14. Singh, J.S.; Kumar, A.; Rai, A.N.; Singh, D.P. Cyanobacteria: A precious bio-resource in agriculture, ecosystem, and environmental sustainability. Front. Microbiol. 2016, 7, 1-19. [CrossRef] [PubMed]

15. Rastogi, R.P.; Sinha, R.P. Biotechnological and industrial significance of cyanobacterial secondary metabolites. Biotechnol. Adv. 2009, 27, 521-539. [CrossRef] [PubMed]

16. Cantoral Uriza, E.A.; Asencio, A.D.; Aboal, M. Are we underestimating benthic cyanotoxins? extensive sampling results from Spain. Toxins 2017, 9, 385. [CrossRef] [PubMed]

17. Cruz-Rivera, E.; Paul, V.J. Chemical deterrence of a cyanobacterial metabolite against generalized and specialized grazers. J. Chem. Ecol. 2007, 33, 213-217. [CrossRef]

18. Sneed, J.M.; Meickle, T.; Engene, N.; Reed, S.; Gunasekera, S.; Paul, V.J. Bloom dynamics and chemical defenses of benthic cyanobacteria in the Indian River Lagoon, Florida. Harmful Algae 2017, 69, 75-82. [CrossRef]

19. Baudinat, C. Contribution à l'Etude de la Maturation de Péloïdes: Application aux Stations Thermales de Balaruc-les-Bains (34) et Cransac (12). Ph.D. Thesis, Université de Montpellier, Montpellier, France, 1986.

20. Dupuis, E. Pré-Etude Relative à l'Evaluation de la Production Algale des Eaux Thermales de Balruc-les-Bain; Science Sorbonne Universite: Montpellier, France, 1987.

21. Counilh, P.; Gibert, J.-L. Process for Preparing Thermal Muds, Muds Thus Obtained and Their Uses. European Patent EP0646647A1, 5 April 1995.

22. Lalli, A.; Andreoli, C.; Ceschi-Berrini, C.; De Appolonia, F.; Marcolongo, G. Anti-Inflammatory Active Principles in Euganean Thermal Mud. European Patent PAT-EP1571203 05100038.8, 1 May 2005.

23. Zampieri, R.M.; Adessi, A.; Caldara, F.; Codato, A.; Furlan, M.; Rampazzo, C.; De Philippis, R.; La Rocca, N.; Dalla Valle, L. Anti-Inflammatory Activity of Exopolysaccharides from Phormidium sp. ETS05, the Most Abundant Cyanobacterium of the Therapeutic Euganean Thermal Muds, Using the Zebrafish Model. Biomolecules 2020, 10, 582. [CrossRef]

24. Hamlaoui, S. Isolement, Culture et Analyses Toxicologiques de Souches de Micro-Algues et de Cyanobactéries des Eaux Thermales de Balaruc-les-Bains; Science Sorbonne Universite: Paris, France, 2014.

25. Singh, R.; Parihar, P.; Singh, M.; Bajguz, A.; Kumar, J.; Singh, S.; Singh, V.P.; Prasad, S.M. Uncovering potential applications of cyanobacteria and algal metabolites in biology, agriculture and medicine: Current status and future prospects. Front. Microbiol. 2017, 8, 515. [CrossRef]

26. Ziemert, N.; Alanjary, M.; Weber, T. The evolution of genome mining in microbes-a review. Nat. Prod. Rep. 2016, 33, 988-1005. [CrossRef] [PubMed]

27. Duval, C.; Hamlaoui, S.; Piquet, B.; Toutirais, G.; Yéprémian, C.; Reinhardt, A.; Duperron, S.; Marie, B.; Demay, J.; Bernard, C. Characterization of cyanobacteria isolated from thermal muds of Balaruc-Les-Bains (France) and description of a new genus and species Pseudo-chroococcus couteii. bioRxiv 2020. [CrossRef]

28. Bankevich, A.; Nurk, S.; Antipov, D.; Gurevich, A.A.; Dvorkin, M.; Kulikov, A.S.; Lesin, V.M.; Nikolenko, S.I.; Pham, S.; Prjibelski, A.D.; et al. SPAdes: A new genome assembly algorithm and its applications to single-cell sequencing. J. Comput. Biol. 2012, 19, 455-477. [CrossRef] [PubMed]

29. Wick, R.R.; Judd, L.M.; Gorrie, C.L.; Holt, K.E. Unicycler: Resolving bacterial genome assemblies from short and long sequencing reads. PLoS Comput. Biol. 2017, 13, e1005595. [CrossRef]

30. Koren, S.; Walenz, B.P.; Berlin, K.; Miller, J.R.; Bergman, N.H.; Phillippy, A.M. Canu: Scalable and accurate long-read assembly via adaptive K-mer weighting and repeat separation. Genome Res. 2017, 27, 722-736. [CrossRef] [PubMed]

31. Von Meijenfeldt, F.A.B.; Arkhipova, K.; Cambuy, D.D.; Coutinho, F.H.; Dutilh, B.E. Robust taxonomic classification of uncharted microbial sequences and bins with CAT and BAT. Genome Biol. 2019, 20, 217. [CrossRef]

32. Vallenet, D.; Calteau, A.; Dubois, M.; Amours, P.; Bazin, A.; Beuvin, M.; Burlot, L.; Bussell, X.; Fouteau, S.; Gautreau, G.; et al MicroScope: An integrated platform for the annotation and exploration of microbial gene functions through genomic, pangenomic and metabolic comparative analysis. Nucleic Acids Res. 2019. [CrossRef] 
33. Blin, K.; Shaw, S.; Steinke, K.; Villebro, R.; Ziemert, N.; Lee, S.Y.; Medema, M.H.; Weber, T. AntiSMASH 5.0: Updates to the secondary metabolite genome mining pipeline. Nucleic Acids Res. 2019, 47, W81-W87. [CrossRef]

34. Kautsar, S.A.; Blin, K.; Shaw, S.; Navarro-Muñoz, J.C.; Terlouw, B.R.; Van Der Hooft, J.J.J.; Van Santen, J.A.; Tracanna, V.; Suarez Duran, H.G.; Pascal Andreu, V.; et al. MIBiG 2.0: A repository for biosynthetic gene clusters of known function. Nucleic Acids Res. 2020, 48, D454-D458. [CrossRef]

35. Ras, J.; Claustre, H.; Uitz, J. Spatial variability of phytoplankton pigment distributions in the Subtropical South Pacific Ocean: Comparison between in situ and predicted data. Biogeosciences 2008, 5, 353-369. [CrossRef]

36. Yéprémian, C.; Catherine, A.; Bernard, C.; Congestri, R.; Elersek, T.; Pilkaityte, R. Phycocyanin Extraction and Determination. In Handbook of Cyanobacterial Monitoring and Cyanotoxin Analysis; John Wiley \& Sons, Ltd.: Chichester, UK, $2017 ;$ pp. 335-338.

37. Jones, M.R.; Pinto, E.; Torres, M.A.; Dörr, F.; Mazur-Marzec, H.; Szubert, K.; Tartaglione, L.; Dell'Aversano, C.; Miles, C.O.; Beach, D.G.; et al. Comprehensive database of secondary metabolites from cyanobacteria. bioRxiv 2020. [CrossRef]

38. Olivon, F.; Elie, N.; Grelier, G.; Roussi, F.; Litaudon, M.; Touboul, D. MetGem Software for the Generation of Molecular Networks Based on the t-SNE Algorithm. Anal. Chem. 2018, 90, 13900-13908. [CrossRef] [PubMed]

39. Houël, E.; Nardella, F.; Jullian, V.; Valentin, A.; Vonthron-Sénécheau, C.; Villa, P.; Obrecht, A.; Kaiser, M.; Bourreau, E.; Odonne, G.; et al. Wayanin and guaijaverin, two active metabolites found in a Psidium acutangulum Mart. ex DC (syn. P. persoonii McVaugh) (Myrtaceae) antimalarial decoction from the Wayana Amerindians. J. Ethnopharmacol. 2016, 187, 241-248. [CrossRef] [PubMed]

40. Abboud, D.; Daubeuf, F.; Do, Q.T.; Utard, V.; Villa, P.; Haiech, J.; Bonnet, D.; Hibert, M.; Bernard, P.; Galzi, J.L.; et al. A strategy to discover decoy chemokine ligands with an anti-inflammatory activity. Sci. Rep. 2015, 5, 14746. [CrossRef]

41. Calas, A.G.; Hanak, A.S.; Jaffré, N.; Nervo, A.; Dias, J.; Rousseau, C.; Courageux, C.; Brazzolotto, X.; Villa, P.; Obrecht, A.; et al. Efficacy assessment of an uncharged reactivator of nop-inhibited acetylcholinesterase based on tetrahydroacridine pyridinealdoxime hybrid in mouse compared to pralidoxime. Biomolecules 2020, 10, 858. [CrossRef]

42. Zhang, J.M.; An, J. Cytokines, inflammation, and pain. Int. Anesthesiol. Clin. 2007, 45, 27-37. [CrossRef]

43. Liu, T.; Zhang, L.; Joo, D.; Sun, S.C. NF-кB signaling in inflammation. Signal Transduct. Target. Ther. 2017, 2, 17023. [CrossRef]

44. Cornet, L.; Meunier, L.; Van Vlierberghe, M.; Léonard, R.R.; Durieu, B.; Lara, Y.; Misztak, A.; Sirjacobs, D.; Javaux, E.J.; Philippe, H.; et al. Consensus assessment of the contamination level of publicly available cyanobacterial genomes. PLoS ONE 2018, 13, e0200323. [CrossRef]

45. NCBI Genome: Cyanobacteria Overview. Available online: https://www.ncbi.nlm.nih.gov/genome/?term=txid1117 (accessed on 16 June 2020).

46. Alvarenga, D.O.; Fiore, M.F.; Varani, A.M. A metagenomic approach to cyanobacterial genomics. Front. Microbiol. 2017, 8, 809. [CrossRef]

47. Parks, D.H.; Imelfort, M.; Skennerton, C.T.; Hugenholtz, P.; Tyson, G.W. CheckM: Assessing the quality of microbial genomes recovered from isolates, single cells, and metagenomes. Genome Res. 2015, 25, 1043-1055. [CrossRef]

48. Donia, M.S.; Ravel, J.; Schmidt, E.W. A global assembly line for cyanobactins. Nat. Chem. Biol. 2008, 4, 341-343. [CrossRef] [PubMed]

49. Degnan, B.M.; Hawkins, C.J.; Lavin, M.F.; McCaffrey, E.J.; Parry, D.L.; Van Den Brenk, A.L.; Watters, D.J. New Cyclic Peptides with Cytotoxic Activity from the Ascidian Lissoclinum patella. J. Med. Chem. 1989, 32, 1349-1354. [CrossRef] [PubMed]

50. Banker, R.; Carmeli, S. Tenuecyclamides A-D, cyclic hexapeptides from the cyanobacterium Nostoc spongiaeforme var. tenue. J. Nat. Prod. 1998, 61, 1248-1251. [CrossRef] [PubMed]

51. Lobo, V.; Patil, A.; Phatak, A.; Chandra, N. Free radicals, antioxidants and functional foods: Impact on human health. Pharmacogn. Rev. 2010, 4, 118-126. [CrossRef]

52. Stahl, W.; Sies, H. Antioxidant activity of carotenoids. Mol. Aspects Med. 2003, 24, 345-351. [CrossRef]

53. Lanfer-Marquez, U.M.; Barros, R.M.C.; Sinnecker, P. Antioxidant activity of chlorophylls and their derivatives. Food Res. Int. 2005, 38, 885-891. [CrossRef]

54. Romay, C.; Gonzalez, R.; Ledon, N.; Remirez, D.; Rimbau, V. C-Phycocyanin: A Biliprotein with Antioxidant, Anti-Inflammatory and Neuroprotective Effects. Curr. Protein Pept. Sci. 2003, 4, 207-216. [CrossRef]

55. Finkel, Z.V.; Follows, M.J.; Liefer, J.D.; Brown, C.M.; Benner, I.; Irwin, A.J. Phylogenetic diversity in the macromolecular composition of microalgae. PLoS ONE 2016, 11, e0155977. [CrossRef]

56. Kosourov, S.; Murukesan, G.; Jokela, J.; Allahverdiyeva, Y. Carotenoid biosynthesis in calothrix sp. 336/3: Composition of carotenoids on full medium, during diazotrophic growth and after long-term H2photoproduction. Plant Cell Physiol. 2016, 57, 2269-2282. [CrossRef]

57. Hirschberg, J.; Chamovitz, D. Carotenoids in Cyanobacteria BT-The Molecular Biology of Cyanobacteria. In The Molecular Biology of Cyanobacteria; Springer: Dordrecht, The Netherlands, 1994; pp. 559-579. ISBN 978-94-011-0227-8.

58. Liang, C.; Zhao, F.; Wei, W.; Wen, Z.; Qin, S. Carotenoid biosynthesis in cyanobacteria: Structural and evolutionary scenarios based on comparative genomics. Int. J. Biol. Sci. 2006, 2, 197-207. [CrossRef]

59. Jain, S.; Prajapat, G.; Abrar, M.; Ledwani, L.; Singh, A.; Agrawal, A. Cyanobacteria as efficient producers of mycosporine-like amino acids. J. Basic Microbiol. 2017, 57, 715-727. [CrossRef]

60. Pathak, J.; Ahmed, H.; Rajneesh; Singh, S.P.; Häder, D.P.; Sinha, R.P. Genetic regulation of scytonemin and mycosporine-like amino acids (MAAs) biosynthesis in cyanobacteria. Plant Gene 2019, 17, 100172. [CrossRef] 
61. Kageyama, H.; Waditee-Sirisattha, R. Mycosporine-Like Amino Acids as Multifunctional Secondary Metabolites in Cyanobacteria: From Biochemical to Application Aspects, 1st ed.; Elsevier, B.V.: Amsterdam, The Netherlands, 2018; Volume 59, ISBN 9780444641793.

62. Katoch, M.; Mazmouz, R.; Chau, R.; Pearson, L.A.; Pickford, R.; Neilan, B.A. Heterologous production of cyanobacterial mycosporine-like amino acids mycosporine-ornithine and mycosporine-lysine in Escherichia coli. Appl. Environ. Microbiol. 2016, 82, 6167-6173. [CrossRef] [PubMed]

63. Durai, P.; Batool, M.; Choi, S. Structure and effects of cyanobacterial lipopolysaccharides. Mar. Drugs 2015, 13, 4217-4230. [CrossRef] [PubMed]

64. Stewart, I.; Schluter, P.J.; Shaw, G.R. Cyanobacterial lipopolysaccharides and human health-A review. Environ. Health Glob. Access Sci. Source 2006, 5, 1-23. [CrossRef] [PubMed]

65. Lauffenburger, D.A.; Horwitz, A.F. Cell migration: A physically integrated molecular process. Cell 1996, 84, 359-369. [CrossRef]

66. Ridley, A.J.; Schwartz, M.A.; Burridge, K.; Firtel, R.A.; Ginsberg, M.H.; Borisy, G.; Parsons, J.T.; Horwitz, A.R. Cell Migration: Integrating Signals from Front to Back. Science 2003, 302, 1704-1709. [CrossRef]

67. Sevimli Gur, C.; Kiraz Erdogan, D.; Onbasılar, I.; Atilla, P.; Cakar, N.; Gurhan, I.D. In vitro and in vivo investigations of the wound healing effect of crude Spirulina extract and C-phycocyanin. J. Med. Plants Res. 2013, 7, 425-433.

68. Sarkar, P.; Stefi, R.V.; Pasupuleti, M.; Paray, B.A.; Al-Sadoon, M.K.; Arockiaraj, J. Antioxidant molecular mechanism of adenosyl homocysteinase from cyanobacteria and its wound healing process in fibroblast cells. Mol. Biol. Rep. 2020, 47, 1821-1834. [CrossRef]

69. Yin, H.; Chen, C.Y.; Liu, Y.W.; Tan, Y.J.; Deng, Z.L.; Yang, F.; Huang, F.Y.; Wen, C.; Rao, S.S.; Luo, M.J.; et al. Synechococcus elongatus PCC7942 secretes extracellular vesicles to accelerate cutaneous wound healing by promoting angiogenesis. Theranostics 2019, 9, 2678-2693. [CrossRef]

70. Cai, W.; Salvador-Reyes, L.A.; Zhang, W.; Chen, Q.Y.; Matthew, S.; Ratnayake, R.; Seo, S.J.; Dolles, S.; Gibson, D.J.; Paul, V.J.; et al Apratyramide, a Marine-Derived Peptidic Stimulator of VEGF-A and Other Growth Factors with Potential Application in Wound Healing. ACS Chem. Biol. 2018, 13, 91-99. [CrossRef] [PubMed]

71. Zervou, S.K.; Gkelis, S.; Kaloudis, T.; Hiskia, A.; Mazur-Marzec, H. New microginins from cyanobacteria of Greek freshwaters. Chemosphere 2020, 248, 125961. [CrossRef] [PubMed]

72. Reshef, V.; Carmeli, S. Protease inhibitors from a water bloom of the cyanobacterium Microcystis aeruginosa. Tetrahedron 2001, 57, 2885-2894. [CrossRef]

73. Lifshits, M.; Zafrir-Ilan, E.; Raveh, A.; Carmeli, S. Protease inhibitors from three fishpond water blooms of Microcystis spp. Tetrahedron 2011, 67, 4017-4024. [CrossRef]

74. Ishida, K.; Kato, T.; Murakami, M.; Watanabe, M.; Watanabe, M.F. Microginins, zinc metalloproteases inhibitors cyanobacterium Microcystis aeruginosa. Tetrahedron 2000, 56, 8643-8656. [CrossRef]

75. Okino, T.; Matsuda, H.; Murakami, M.; Yamaguchi, K. Microginin, an angiotensin-converting enzyme inhibitor from the blue-green alga Microcystis aeruginosa. Tetrahedron Lett. 1993, 34, 501-504. [CrossRef]

76. Nath Bagchi, S.; Sondhia, S.; Kumar Agrawal, M.; Banerjee, S. An angiotensin-converting enzyme-inhibitory metabolite with partial structure of microginin in a cyanobacterium Anabaena fertilissima CCC597, producing fibrinolytic protease. J. Appl. Phycol. 2016, 28, 177-180. [CrossRef]

77. Hanke, T.; Merk, D.; Steinhilber, D.; Geisslinger, G.; Schubert-Zsilavecz, M. Small molecules with anti-inflammatory properties in clinical development. Pharmacol. Ther. 2016, 157, 163-187. [CrossRef]

78. Ridker, P.M.; Lüscher, T.F. Anti-inflammatory therapies for cardiovascular disease. Eur. Heart J. 2014, 35, 1782-1791. [CrossRef]

79. Rastogi, R.P.; Sonani, R.R.; Madamwar, D. Cyanobacterial Sunscreen Scytonemin: Role in Photoprotection and Biomedical Research. Appl. Biochem. Biotechnol. 2015, 176, 1551-1563. [CrossRef]

80. Bruno, A.; Rossi, C.; Marcolongo, G.; Di Lena, A.; Venzo, A.; Berrie, C.P.; Corda, D. Selective in vivo anti-inflammatory action of the galactolipid monogalactosyldiacylglycerol. Eur. J. Pharmacol. 2005, 524, 159-168. [CrossRef] [PubMed]

81. Tateo, F.; Ravaglioli, A.; Andreoli, C.; Bonina, F.; Coiro, V.; Degetto, S.; Giaretta, A.; Menconi Orsini, A.; Puglia, C.; Summa, V. The in-vitro percutaneous migration of chemical elements from a thermal mud for healing use. Appl. Clay Sci. 2009, 44, 83-94. [CrossRef]

82. Tolomio, C.; Ceschi-Berrini, C.; Moschin, E.; Galzigna, L. Colonization by diatoms and antirheumatic activity of thermal mud. Cell Biochem. Funct. 1999, 17, 29-33. [CrossRef]

83. Centini, M.; Tredici, M.R.; Biondi, N.; Buonocore, A.; Maffei Facino, R.; Anselmi, C. Thermal mud maturation: Organic matter and biological activity. Int. J. Cosmet. Sci. 2015, 37, 339-347. [CrossRef] [PubMed]

84. Giorgio, A.; Carraturo, F.; Aliberti, F.; De Bonis, S.; Libralato, G.; Morra, M.; Guida, M. Characterization of microflora composition and antimicrobial activity of algal extracts from Italian thermal muds. J. Nat. Sci. Biol. Med. 2018, 9, 150-158.

85. Beliaev, A.S.; Romine, M.F.; Serres, M.; Bernstein, H.C.; Linggi, B.E.; Markillie, L.M.; Isern, N.G.; Chrisler, W.B.; Kucek, L.A.; Hill, E.A.; et al. Inference of interactions in cyanobacterial-heterotrophic co-cultures via transcriptome sequencing. ISME J. 2014, 8, 2243-2255. [CrossRef]

86. Briand, E.; Reubrecht, S.; Mondeguer, F.; Sibat, M.; Hess, P.; Amzil, Z.; Bormans, M. Chemically mediated interactions between Microcystis and Planktothrix: Impact on their growth, morphology and metabolic profiles. Environ. Microbiol. 2019, 21, 1552-1566. [CrossRef] 
87. Fischer, W.J.; Altheimer, S.; Cattori, V.; Meier, P.J.; Dietrich, D.R.; Hagenbuch, B. Organic anion transporting polypeptides expressed in liver and brain mediate uptake of microcystin. Toxicol. Appl. Pharmacol. 2005, 203, 257-263. [CrossRef]

88. Luesch, H.; Moore, R.E.; Paul, V.J.; Mooberry, S.L.; Corbett, T.H. Isolation of dolastatin 10 from the marine cyanobacterium Symploca species VP642 and total stereochemistry and biological evaluation of its analogue symplostatin 1. J. Nat. Prod. 2001, 64, 907-910. [CrossRef]

89. Salvador-Reyes, L.A.; Luesch, H. Biological targets and mechanisms of action of natural products from marine cyanobacteria. Nat. Prod. Rep. 2015, 32, 478-503. [CrossRef]

90. Shishido, T.K.; Jokela, J.; Kolehmainen, C.-T.; Fewer, D.P.; Wahlsten, M.; Wang, H.; Rouhiainen, L.; Rizzi, E.; De Bellis, G.; Permi, P.; et al. Antifungal activity improved by coproduction of cyclodextrins and anabaenolysins in Cyanobacteria. Proc. Natl. Acad. Sci. USA 2015, 112, 13669-13674. [CrossRef] [PubMed] 